\title{
THE CORRELATION BETWEEN STUDENTS' MASTERY ON LEXICAL COLLOCATION AND THEIR READING COMPREHENSION
}

\author{
Wulan Trisviana \\ English Education Study Program, Department of Language and Art University of \\ Bengkulu \\ wulantrisviana@gmail.com \\ Rudi Afriazi \\ English Education Study Program, Department of Language and Art University of \\ Bengkulu \\ rudiafriazi88@gmail.com \\ Gita Mutiara Hati \\ English Education Study Program, Department of Language and Art University of \\ Bengkulu \\ gitawitanto@gmail.com
}

\begin{abstract}
The aims of this research were to find out the correlation between students' mastery of lexical collocation and their reading comprehension. This research applied correlational study which used quantitative design. The subjects were 66 of the Fifth-Semester Students of English Education Study Program at University of Bengkulu in Academic Year 2018/2019. The data were collected from two instruments: (1) lexical collocation test was used to get data about students' mastery of lexical collocation and (2) reading comprehension test was used to get data about students' reading comprehension achievement. The result of the two instruments counted by using Pearson's Product Moment formula and checked it by using SPSS 22 Program. The conclusion were (1) The result score of lexical collocation test showed that $53 \%$ of the students got score over 70, it means that half of the total subject of the students have a good knowledge of collocation especially in lexical collocation. (2) There was high significant correlation between students' mastery of lexical collocation and their reading comprehension. The result of calculation using Pearson Product moment formula and SPSS 22 Program can be seen in table 4.1 which showed the score of arithmetic $r>$ the score of $r$ table $(0,825>0,315)$. It means that Ha was accepted and $\mathrm{HO}$ was rejected.
\end{abstract}




\begin{abstract}
ABSTRAK
Tujuan dari penelitian ini adalah untuk menemukan korelasi antara nilai leksikal kolokasi dan nilai kemampuan membaca mereka. Penelitian ini menggunakan jenis penelitian hubungan yang berbentuk quantitative. Subjek terdiri dari 66 mahasiswa dari semester 5 Program Studi Pendidikan Bahasa Inggris Universitas Bengkulu tahun ajaran 2018/2019. Data dikumpulkan dari dua instrument: (1) Nilai pemahaman mahasiswa pada tes leksikal kolokasi dan (2) nilai kemampuan mahasiswa dalam membaca. Hasil dari kedua instrument dihiung menggunakan Perason's product moment dan di cek menggunakan Program SPSS 22. Kesimpulannya adalah: (1) hasil dari nilai test pemahaman siswa dalam lexical collocation menunjukan bahwa 53\% mahasiswa mendapatkan nilai diatas 70, itu menunjukkan bahwa hampir setengah dari total subjek mempunyai pemahaman yang baik tentang leksikal kolokasi. (2) Ada hubungan yang sangat signifikan antara nilai pemahaman leksikal kolokasi dan nilai kemampuan membaca. Hasil perhitungan menggunakan rumus Pearson's Product moment dan SPSS 22 dapat dilihat pada table 4.1 yang menunjukkan nilai aritmatik $5>$ nilai table $r(0,825>0,315)$. It a artinya Ha diterima dan $\mathrm{HO}$ ditolak.
\end{abstract}

Kata Kunci: nilai Leksikal Kolokasi, nilai membaca

\title{
Introduction
}

One of the important skill that must be mastered in learning English is Reading. Reading is an important skill because one key to get a knowledge, it supported the theory from McNamara (2007) states that the most common and effective technique in obtaining knowledge is reading comprehension, because the readers must understand what they read about. When the learners read the article and they find some strange vocabulary that they unusually hear, they will get confused and they cannot get the meaning of what they read. Nowadays, the ability to comprehend the English is necessary for millions of people. By understanding English, many people are able to read many kinds of English texts. Reading occurs when someone looks into a written text and starts to absorb the information from the written linguistic message. One of the important things to do is to combine the word into a good sentence so that it is easy and natural to read. 
Thornbury (2002) explains that there are at least 6 types of vocabulary. The types are word classes, word families, word formation, multi-word units, collocation, and homonyms. The six types must be learned and mastered by the EFL students in order to improve as well as to increase their English vocabulary. In relation to the mastery of English collocation, the students whose non-native speaker must understand these types of vocabulary, especially in collocation.

The aim of understanding English collocation is to make the students increase learners' skill, such as writing skill, reading skill, and etc, and also the students know in what context the student can use the word for instance verbs do and make can be used with a different situation. based on the result of the researcher's mini-observation to some of the students of fifth-semester of English Education Study program for example like 33,3\% students still use the word yellow hair rather than blond hair, and also $66,7 \%$ students still use right truth rather than plain truth. So, the students are still confuse to decide what is the appropriate word which closely associated together in lexical collocation. It related to reading comprehension test, when they do the reading test and find some lexical collocation or may be some strange vocabulary which they unsually hear, they will get confused to interpret and understand the meaning of the reading test. And also, the students cannot recognize the collocation area in the reading text because they have lack of knowledge about the collocation.

The scope of this research limited on the lexical collocation and also focus to find the correlation between students' mastery on lexical collocation mastery and their reading comprehension achievement, particularly restricted to lexical collocation and reading comprehension text on fifth-semester students of English Education Study Program at University of Bengkulu in the academic year of $2018 / 2019$. This research paper is aimed to find out the correlation between students' mastery on lexical collocation fifth-semester students of English Department and their reading comprehension achievement of Universitas Bengkulu in academic year 2018/2019.

\section{Method}

In this study, the researcher used a correlational research design while the type of data was a quantitative one. In correlational research design, investigation used 
the correlational statistical test to describe and measure the degree of association (or relationship) between two or more variables or sets of scores (Creswell 2012). In this research design, there was a correlation coefficient, which is a numerical index that provides information about the strength and direction of the relationship between two variables. It provides information on how the variable is associated. However, the process would be that first: the researcher identified the students' collocational knowledge by using lexical collocation test. Second, by using the reading comprehension test, the students' reading comprehension achievement will be acquired. The next process that the researcher discovered the relationship among variables through Pearson-Product Moment and check it by SPSS based in the result of the collocation test and reading comprehension test and interpret the result of the correlation between two variable.

This research involved the fifth-semester students of the English Education Study Program at Universitas Bengkulu in Academic Year 2018/2019. The total subjects are 78 students which consist of 2 classes, class A and class B. 12 students from both of the class were used in try out instrument test and 66 students were used in real tests. So, in this research, the researcher doing research to 66 students of $5^{\text {th }}$ semester of English Education Study Program in Universitas Bengkulu on academic year 2018/2019.

The instruments that used in this research are lexical collocation test and reading comprehension test. both of instruments are adapted from the same sourches which is Mc.Carthy and O'Dell book the title is English Collocation for Intermediate \& Advanced use (2008). The researcher also has done the try-out test to check whether both of the instruments were validity and reliablity or not. The result of the try-out was both of the instrument were valid and reliable.

The students asked to complete both of the test which consist 50 questions of lexical collocation test and 25 questions from reading comprehension test of multiple choice within 60 minutes. The questions were considered not too difficult and possible for them to complete. Each of the questions had 4 choices in which only one option was right and the other three was distractions. The data were analysed by using Pearson Product Moment Formula and also checked by SPSS 22 Program. After finding out whether there is a significant correlation or not, the next step is interpreting. To interpret 
Volume 3 number 12019 
the correlation coefficient, the following criteria from Cohen, Manion and Marrison (2007, p.536) used. Then, to find out the significant between two variables, the researcher used the Paired Sample T Test with IBM SPSS Statistic 22. The basic of decision making in this test is if the value of Sig (2-tailed) $<0.05$, then there is significant differences between 2 variables. Meanwhile, if the value of Sig (2-tailed) >0.05, then there is no significant differences between 2 variables.

Both of the tests were done one time. The test was administered for two days in two different classes (November $21^{\text {th }}$ and $26^{\text {th }}, 2018$ ) at $10.00-11.00 \mathrm{am}$. The total subjects were 66 students from $5^{\text {th }}$ semester students of English Education Study Program of Universitas Bengkulu.

\section{Results}

Based on the analysis of the data, the researcher get scores from both of the test: lexical collocation test and reading comprehension test. Lexical Collocation test was form of fill in the blank with multiple choices which consisted of 50 items. The researcher asked the students to choose the best answer to complete the blank space of the sentences. The researcher gave 40 minutes for the students to answer the test. Firstly, the researcher counted the sum of the score for each student. Then the researcher make percentage based on the scores of the students to see the students' mastery on lexical collocation.

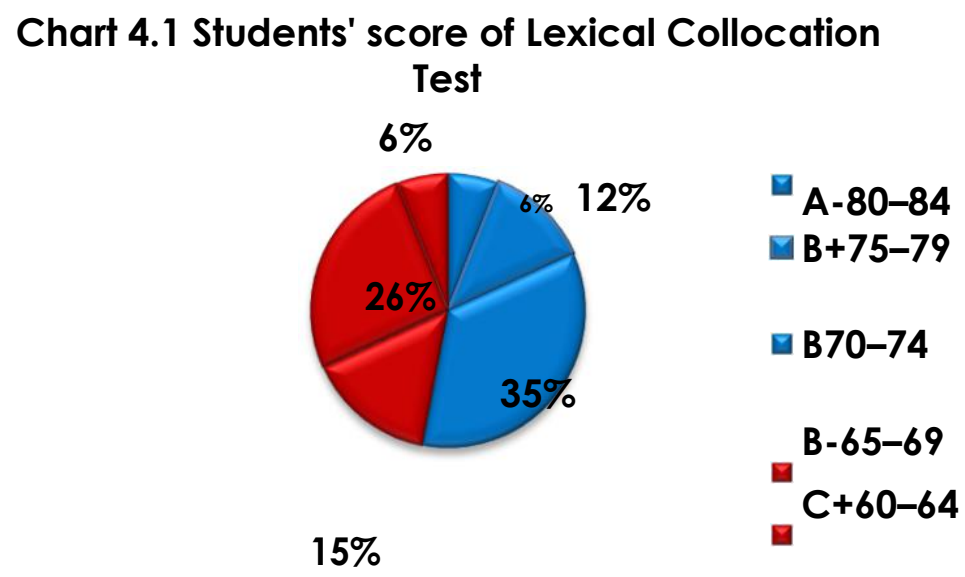

Based on the pie chart, 53\% (blue area) of students got score over 70 which present that half of students have a good level of collocation and can understand the application of lexical collocation in the sentence. Meanwhile, $47 \%$ (red area) of students got score under 70 which present that the students have lack knowledge of 
collocation and cannot understand the application of lexical collocation in the sentence.

Meanwhile, for reading comprehension test, the researcher asked the students to choose the best answer to answer the question based on the text. The researcher gave 20 minutes for the students to answer the test.

\section{Chart 4.2 Students' Score of Reading} Comprehension

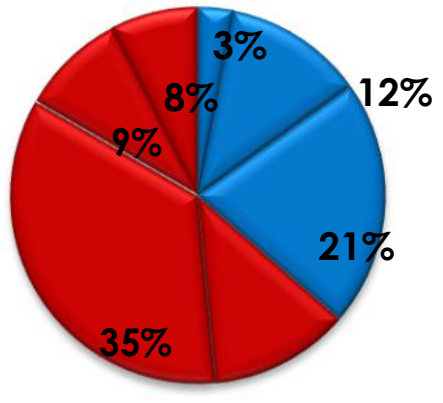

$12 \%$

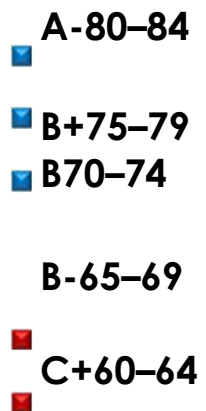

$\square$ C $55-59$

Based on the pie chart, 36\% (blue area) of students got score over 70 which present that students have a good score in reading comprehension. Meanwhile, $64 \%$ (red area) of students got score under 70 which present that half of the students have low score of reading comprehension, it means in the test half of the students still cannot recognize the lexical collocation test and cannot understand the meaning of it.

To identify whether collocation knowledge of students has any correlation with students' reading comprehension achievement or not, the researcher applied Pearson-Product Moment Correlation Coefficient. By using the same statistical method, Pearson-Product Moment, the correlation between students' Lexical Collocation (X) and Reading Comprehension (Y) achievement will establish.

The result from the researchers' calculation of the two variables calculated by Pearsons' product moment. The other previous researcher also used the Pearson-product moment correlation coefficient and got the relevant result for their research. The computation employed will use Pearson product-moment and get the result rxy

$=0,825$. 
To ensure the result of the calculation above, the researcher used SPSS 22 program in order to know whether the result of calculation that the researcher did manually was accurate. The Description of the calculation of SPSS was described below:

Table. 4.1

Correlation between students' mastery of Lexical Collocation toward their Reading Comprehension

\begin{tabular}{|ll|r|r|}
\hline & \multicolumn{1}{c|}{$\begin{array}{c}\text { Lexical } \\
\text { Collocation }\end{array}$} & $\begin{array}{c}\text { Reading } \\
\text { Comprehension }\end{array}$ \\
\hline & Correlation & 1 &, $826^{* *}$ \\
& Sig. (2-tailed) & &, 000 \\
& $\mathrm{~N}$ & 66 & 66 \\
\hline Reading & Pearson &, $826^{* *}$ & 1 \\
Comprehension & Correlation & & \\
& Sig. (2-tailed) & & \\
& $\mathrm{N}$ & 600 & 66 \\
\hline
\end{tabular}

**. Correlation is significant at the 0.01 level (2-tailed).

The result of both calculation (manual and SPSS calculation) is similar. The result showed that rxy is 0,826 , it was higher than $r$ table. It means that there is no mistake in calculation process and there was correlation between students' mastery of lexical collocation toward their reading comprehension.

Table. 4.2

Paired Samples Test

\begin{tabular}{|c|c|c|c|}
\hline & & & Pair 1 \\
\hline & & & $\begin{array}{c}\text { Lexical Collocation - Reading } \\
\text { Comprehension }\end{array}$ \\
\hline Paired & Mean & & $\begin{array}{r}2,727 \\
\end{array}$ \\
\hline & Std. Deviation & & 4,334 \\
\hline & Std. Error Mean & &, 534 \\
\hline & $\begin{array}{l}95 \% \text { Confidence } \\
\text { Interval of the }\end{array}$ & $\begin{array}{l}\text { Lowe } \\
\text { r }\end{array}$ & 1,662 \\
\hline & Difference & $\begin{array}{l}\text { Uppe } \\
r\end{array}$ & 3,793 \\
\hline $\mathrm{T}$ & & & 5,112 \\
\hline Df & & & 65 \\
\hline Sig. (2-taile & & &, 000 \\
\hline
\end{tabular}


Based on the score of $r x y=0,825$, it indicates that rxy is higher than $r$, in which $0,825>0,315$ and the score of tvalue $=5,112$ is compares by ttable of $5 \%=$ 1,997, that is tvalue is higher than ttable, 5,112>1,997. As a result, the correlation between the students' mastery on lexical collocation and their reading comprehension is positive or significant. So the null hypothesis $(\mathrm{HO})$ which states that there is no significant correlation between students' mastery on lexical collocation and their reading comprehension at the $5^{\text {th }}$ semester students of English Education Study Program at University of Bengkulu on academic year 2018/2019 is rejected and the alternative hypothesis (Ha) which states there is significant correlation between students' mastery on lexical collocation and their reading comprehension at the $5^{\text {th }}$ semester students of English Education Study Program of Universitas Bengkulu on academic year $2018 / 2019$ is accepted.

\section{Discussion}

Based on the result of the research, it is found that half of the total subject of the research of fifth semester students of English Education Study Program in academic year 2018/2019 got score at least 70 of lexical collocation test. Owing to this facts, the researcher relate to the expert by Bahns (1993) and Bonk (2000) state, it can be concluded that a good level of collocation knowledge may be regarded as one of the last stages of second-language acquisition. It means that if the students' have a good level in collocation especially in lexical collocation the students also have a good level in English Skills, because if the EFL students have a good level in collocation, it will help the students increase the range of English Vocabulary, for example the students the students can choosing a combination of words that fits the context better and has more precise meaning. The students also can speak and write English in a more natural and accurate way.

Meanwhile, the result of reading comprehension test sowed that half of the student got score under 70. This finding could mean that other in reading comprehension is very complex. It also supported to the theory by Kwon (2005) that states that studies have shown that reading is not a simple ability but an active and complex psychological process associated with variety factors. It means that some other 
factors effect to students' reading achievement for example like situation and condition of the test, the prior knowledge of the students, and others.

Based on the result, the correlation between the students' mastery on lexical collocation and their reading comprehension is positive or significant. The result of this present research supported to theory from Ganji (2012) stated that lexical collocation has positive effect on the reading ability of the students. The new words should not be presented as single-item vocabularies. It is better to present them as collocation, at least with one or two more items. So it can make the learners can predict and learn what kind of lexical items could occur together.

According to the Cahyo (2015), collocation is one of the important roles in creating cohesion in a discourse (spoken and written), and will further lead to coherences of the message delivered. So the collocation is a determinant factor of the meaning of the words and it will increase the effectiveness of language skill. It can be shows that some the meaning of the word probably have different meaning in the different context and collocation is probably the one that decides the meaning of that word.

Collocation has given considerable contribution to the language learning. Based on this result of this research, a strong relationship was found between the students mastery on lexical collocation and reading comprehension among the $5^{\text {th }}$ semester students of English Education Study Program of Universitas Bengkulu on academic year 2018/2019. If the students have a good level on lexical collocation and understand about the lexical collocation, the students also can get a better understanding while they read a reading text that has several combination of words or collocation. The students can also easily to find the meaning of the collocation if the students can recognize the collocation item in the reading text. Meanwhile, when the students write or speak in English, the students also can easily choose the better combination of the words in natural and accurate way.

\section{Conclusion and Suggestion}

Based on the research finding, it is found that the null hypothesis $(\mathrm{HO})$ is rejected and the alternative hypothesis ( $\mathrm{Ha}$ ) is accepted. The result of this research confirmed to other correlation in previous research. It showed that the collocation especially lexical 
collocation has correlation to the English skills students especially in reading skill and writing skill. If the students have a good level of lexical collocation then it can helped the students can got the better result in reading comprehension. Then it can be concluded that if the students have high scores in lexical collocation, they will also have high scores in reading comprehension. It cause by the lexical collocation on the collocation test also can be found in reading comprehension test, so both of the test are relevant.

In relation to the conclusions, suggestion are given as the following. First for English Lecturers. Based on the fact that the students' mastery on lexical collocation has a high correlation toward their reading comprehension, so English lecturer should consider to put collocation into their teaching material especially in teaching reading skill. The lecturers can improve their capability in many ways to develop a new method of language learning to enhance the knowledge about collocation and reading comprehension by give the example and exercise of collocation while the lecturers teach reading material.

Second for English Students in English Education Study. By knowing that the students' mastery on lexical collocation has contribution for their reading comprehension, it is a must for them to increase their knowledge about the collocation due to it helps them to understand the meaning of the combination of words in the text completely and accurately. The students also should do the exercise of collocation in order to recognize the type of collocation in reading text.

Third for further researcher, The result of this result can be essential for other researchers who would like to investigate and explore more about the collocation problems in the future. In addition, the future researcher can also find out the study between the collocation and any language skills such as listening and speaking skill.

\section{References}

Ahn, S. J. (2009). Knowledge of Collocations and their relation to Reading Proficiency of Korean EFL Learners. Studies in Modern Grammar. Sun Moon University, South Korea : Unpublished Undergraduate Thesis. 
Alyousef, H.S. (2005). Teaching reading comprehension to ESL/EFL learners. The Reading Matrix. Volume 5 No 2.

Bahns, J. (1993). Lexical Collocations: A Constrantive view. ELT Journal:. Volume 47, Issue 1. Oxford University Press; NewYork

Cabaroglu, N. \& Yudarisik, A. (2008). University Instructors' Views about and Approaches to Reading Instruction and Reading Strategies. The Reading Matrix. Volume 8, No. 2.

Cahyo, N. (2015). The correlative study between student's lexical knowledge of collocations toward their reading comprehension. (Undergraduated Thesis) State Institute for Islamic studies Salatiga, Jawa Tengah: Unpublished Undergraduate Thesis.

Cohen,L., Manion,L., \& Morrison,K. (2007). Reseacrh Methods in Education (6 $6^{\text {th }}$ ed.).

New York, NY: Routlage.

Fitriani, D. (2017). The Relationship between Collocational knowledge and Reading Comprehension Achievement of Undergraduated EFL Students of English Education Study Program. (Undergraduated Thesis) UIN Raden Fatah Palembang, Palembang: Unpublished Undergraduate Thesis.

Fraenkel, J.R., Wallen, N.E., \& Hyun, H.H. (2012). How to evaluate research in education (8th edition). New York, NY: McGraw-Hill.

Ganji, M. (2012). The Effect of Reading Comprehension of lexical Collocation Instruction; Subject Matter Knowledge, and Cultural Schema. Theory and Practice in Language Studies. Volume 2, No 1.

Kwon, J. Y. (2005). A Study of proper English Reading Strategies tailored to the Learners' Language Ability (based on TOEIC reading comprehension part). (Unpublished masters' Thesis). Dankook University, Yongin and Cheonan, South Korea. 
Mardiana.(2016) .A Descriptive Study on Student's in Using English Lexical Collocation. (Undergraduated Thesis), Universitas Bengkulu, Bengkulu : Unpublished Undergraduate thesis.

Maskar, P. (2008). The Correlation Between Reading Comprehension and Grammatical Knowledge. Indonesia University of Education, Bandung, Indonesia: Unpublished Undergraduate Thesis

Rahmawati, E.Y. (2016). The Effects of Students' Lexical Knowledge of Collocation and Grammar Mastery Towards Studenst' Reading Comprehension. (Undergraduated Thesis), Universitas Indraprasta, Jakarta : Unpublished Undergraduate Thesis

Thornbury, S. (2009). How to Teach Vocabulary. London: Longman

Widjaya, A.K., \& Imran, I. (2009). English Verb Lexical Collocation. (Undergraduate Thesis) Gunadarma University, Jakarta: Unpublished Undergraduate Thesis

Wiggins, G., \& McTighe,J. (2005) Understanding by Design . Alexandria, VA: Association for Supervision and Curriculum Development (ASCD) Publications, USA.

Woolley, G. (2011). Reading Comprehension: with Learning

Assisting Children

Difficulties. Netherlands: Springer.

Yalmiadi, J. H. (2016). Students' Ability in Using Lexical Collocation in

Descriptive Writing at English Department of Padang State Polytechnic. Journal of English Language Teaching (ELT). Volume 1. No 1.

\section{Writer Information}

\begin{tabular}{|l|l|}
\hline Name & WULAN TRISVIANA \\
\hline Affiliation & $\begin{array}{l}\text { English Education Study Program, Department of } \\
\text { Language } \\
\text { and Art, University of Bengkulu }\end{array}$ \\
\hline Email & Wulantrisviana@gmail.com \\
\hline Phone Number & 081377740332 \\
\hline
\end{tabular}

